\title{
Label-free electrochemical sensor to investigate the effect of tocopherol on generation of superoxide ions following UV irradiation
}

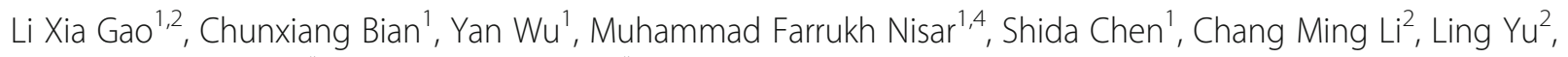
Ping $\mathrm{Ji}^{3}$, Enyi Huang ${ }^{3^{*}}$ and Julia Li Zhong ${ }^{1,3^{*}}$

\begin{abstract}
Background: Generation of reactive oxygen species (ROS), triggered by ultraviolet radiation (UVR), is associated with carcinogenesis of the skin. UV irradiation induced superoxide anion $\left(\mathrm{O2}^{--}\right)$is the key ROS involved in the cellular damage. The cytoprotective efficacy of an unknown anti-oxidant compound can be evaluated by analyzing the production of $\mathrm{O}^{--}$from treated cells.

Methods: In this study, a glass carbon electrode functionalized with nanotube@DNA-Mn3(PO4)2 composite was applied to quantitative determination of generation of highly unstable $\mathrm{O}^{--}$from the melanoma A375 cell line following UVR(UV, UVA and UVB). In addition, the cytoprotective efficacy of anti-oxidant a-tocopherol was evaluated by quantifying the production of $\mathrm{O}^{--}$.

Results: The results showed that, UVR triggers generation of $\mathrm{O}^{--}$in melanoma A375 cells, and a-tocopherol is effective in diminishing the production of $\mathrm{O}^{--}$following UV irradiation. By comparing the conventional cell-survival assays results, we found that our simple and quick electrochemical sensing method can quantify $\mathrm{O}^{--}$generation through the biological activity of an anti-oxidant compound (a-tocopherol).
\end{abstract}

Conclusion: Our label-free electrochemical quantification method for ROS $\left(\mathrm{O} 2^{--}\right.$major) in cells facing UVR stress demonstrates its potential application for high-throughput screening of anti-oxidation compounds.

Keywords: Skin, Electrochemical sensing, $\mathrm{O}_{2}^{--} / \mathrm{ROS}$, UVR, Anti-oxidant screening

\section{Highlighting points}

- A carbon nanotube@DNA-

$\mathrm{Mn}_{3}\left(\mathrm{PO}_{4}\right)_{2}$ compositefunctionalized glass carbon electrode was applied for quantitative determination of $\mathrm{O}_{2}{ }^{\cdot-}$ generation from melanoma cell A375 following UV, UVA, UVB irradiation.

\footnotetext{
*Correspondence: enyihuang@126.com; jlzhong@cqu.edu.cn

LiXia Gao and Chunxiang Bian are co first-authors.

LiXia Gao and Chunxiang Bian contributed equally.

${ }^{3}$ Chongqing Municipal Key laboratory of oral diseases and biomedical sciences, Biomedical Engineering of Higher Education, Chongqing 401147, China

${ }^{1}$ College of Bioengineering \& School of Life Sciences, Chongqing University, Chongqing 400044, China

Full list of author information is available at the end of the article
}

- Label-free Electrochemical Sensor was developed to quantify ROS produced in cells exposed to UVR.

- The anti-oxidation efficacy of tocopherol on melanoma cells towards UV, UVA and UVB were also investigated.

\section{Background}

Ultraviolet (UV) irradiation represents one of the most important environmental impacts for humans and recently became prominent because of the depletion of the atmospheric ozone layer, leads to increased UV irradiation exposure by the majority of population $[1,2]$. It is well documented that UVR can stimulate the production of a series of ROS [3-5], which may cause cellular oxidative stress injury that is believed to be one of the key 
factors in carcinogenesis [6, 7]. For the most part, UV light from sunlight consists of three regions of wavelengths: UVC, UVB and UVA. UVC (100-290 nm) is absorbed by ozone $\left(\mathrm{O}_{3}\right)$ in the upper atmosphere but UVB and UVA reach to earth surface, are the major fractions linked to skin diseases. UVB $(290-320 \mathrm{~nm})$ is absorbed mostly by the epidermis and keratinocyte DNA, while UVA (320-400 $\mathrm{nm}$ ) is primarily oxidative in nature and penetrates more deeply into the dermal layers of the skin $[8,9]$. Since UV fractions reach different biological layers of skin and lead to skin pathology via different cellular pathways. The effects and mechanisms of action initiated by UVA and UVB have been studied extensively [10-12]. For instance, Petersen et al. reported that superoxide anion $\left(\mathrm{O}_{2}{ }^{--}\right)$production in $\mathrm{HaCaT}$ cells was probably linked to DNA damage induced by UVA [13]. UVB can also induce the formation of ROS, leading to cellular damage [14-16]. Among the many ROS species that have been studied, $\mathrm{O}_{2}{ }^{\cdot-}$ is one of the principal radical species [13, 17-19]. It is generated as a reduced intermediate of molecular oxygen in a variety of biological systems. It can easily form hydroxyl radical ( $\left.\mathrm{HO}^{*}\right)$ in the presence of transition metal ions such as $\mathrm{Fe}^{2+}$ and $\mathrm{Cu}^{2+}$ [20]. In addition, the reaction between $\mathrm{O}_{2}{ }^{-}{ }^{-}$and nitric oxide $\left({ }^{\circ} \mathrm{NO}\right)$ leads to the formation of highly reactive peroxynitrite (ONOO-) in the pathogenesis of atherosclerosis and neurodegenerative diseases [21]. As a consequence, efforts have been made to investigate generation of $\mathrm{O}_{2}{ }^{--}$induced by UVR. Particularly, the cytoprotective efficacy of an unknown anti-oxidant compound can be evaluated by analyzing the production of $\mathrm{O}_{2}{ }^{\cdot-}$ from treated cells.

A survey of the literature shows that the main techniques for measuring $\mathrm{O}_{2}{ }^{\cdot-}$ are based on probe-labelling assays. Intracellular fluorescent histochemistry [22], flow cytometry [16] and spectrofluorometric analyses [23, 24] are the most used approaches to characterize ROS such as $\mathrm{O}_{2}{ }^{-}$by using fluorescent dyes such as $2^{\prime}, 7^{\prime}$ dichlorofluorescein diacetate (DCFH-DA), hydroethidine and dihydrorhodamine $[1,23]$. The production of extracellular $\mathrm{O}_{2}{ }^{--}$can also be measured by using the ability of $\mathrm{O}_{2}{ }^{\cdot-}$ to reduce ferricytochrome $\mathrm{C}$ that was added to the cell suspension [25]. Another advanced technique is electron spin resonance (ESR)-spin trapping, was applied for determination of $\mathrm{O}_{2}{ }^{\cdot-}$ generated by UV-irradiated skin cells [10, 24]. Apart from the expensive equipment and complicated assay procedures, these probe-labelling approaches are timeconsuming, difficult to automate and highly prone to interference. The short lifetime of free radicals, such as $\mathrm{O}_{2}{ }^{\cdot-}$, particularly demands fast response of the analytical tool to the changes in concentration to obtain sufficient signal-to-noise ratios $[20,26]$. Electrochemical biosensors have become promising candidates for realtime analysis of free radicals, since they provide the advantages of rather simpler equipment and operation protocols. Li et al. [20] found that an electrochemical biosensor can sense $\mathrm{O}_{2}{ }^{-}$released from cancer cells, using potassium-doped multi-walled carbon nanotubes (KMWNTs)-1-butyl-3-methylimidazoliumhexa-fluorophosphate ionic liquid composite gels [20]. While hydrogen peroxide $\left(\mathrm{H}_{2} \mathrm{O}_{2}\right)$ can directly be measured in cells growing in a 3D matrix environment [27]. These studies indicate that, with intimately coupled biological recognition elements and electrochemical transduction units, an electrochemical biosensor exhibits great potential for facilitating understanding of biological process. Also, the use of a small-volume sample allows expensive reagents, particular for rare clinical biopsy samples, to be conserved and makes the analysis more cost-effective.

In this study, we have designed and developed a labelfree electrochemical sensor that can measure the generation of $\mathrm{O}_{2}{ }^{\cdot-}$ from UVR exposed melanoma A375 cells, though other ROS species e.g. $\mathrm{H}_{2} \mathrm{O}_{2}$ has not been totally excluded. To demonstrate the electrochemical analytical power of this sensor, the protective effects of model anti-oxidant ( $\alpha$-tocopherol) was studied in melanoma A375 cells. The specific objectives to be addressed were [1] to measure generation of $\mathrm{O}_{2}{ }^{\cdot-}$ from melanoma A375 cells following exposure to UVR alone i.e., UV, UVA and UVB; [2] to quantify the production of $\mathrm{O}_{2}{ }^{\cdot-}$ from cells pre-treated with $\alpha$-tocopherol following UVR irradiation; [3] to compare the data from electrochemical measurement, the cell-survival assay and conventional ROS fluorescence staining therefore establish the potential use of the label-free electrochemical method for highthroughput screening of antioxidants.

\section{Methods \\ Materials}

The human melanoma cell A375 (purchased from ATCC) were maintained in RPMI 1640 medium $\left(\mathrm{Gibco}^{\circ}\right)$ supplemented with $10 \%$ foetal calf serum (FCS, Gibco $^{\circ}$ ) with $100 \mathrm{U} \mathrm{mL}-1$ penicillin and $100 \mathrm{U} \mathrm{mL}-1$ streptomycin at $37{ }^{\circ} \mathrm{C}$ in a humidified $5 \% \mathrm{CO}_{2}$ incubator. $\alpha$-Tocopherol was purchased from Sigma-Aldrich. 3-[4,5-Dimethylthiazol-2-yl]-2,5-diphenyltetrazolium bromide (MTT), 2-(4-amidino $\neg$ phenyl)6-indole carbamidine dihydrochloride (DAPI), 2',7'dichlorodihydrofluorescein diacetate (DCFH-DA) and superoxide dismutase (SOD) were purchased from Beyotime Biotechnology (Beijing, China). All other chemicals were purchased from Sigma-Aldrich and were used without further purification, unless otherwise indicated. All solutions were prepared with deionized (DI) water produced by a PURELAB flex system (ELGA Corporation). 


\section{Apparatus}

\section{UV irradiation}

Cells were irradiated with a broad-spectrum UV lamp (MUA-165, Japan). The proportion of UVA and UVB in delivered UV light from this lamp is around 20:1, a ratio close to solar light at mid-day [28]. The lamp exposure time was calculated using an ultraviolet radiometer (Photoelectric Instrument Factory, Beijing Normal University, China). Appropriate glass filters to block UVA, UVB were used respectively to provide fractions of UVA and UVB in the following experiments, according to previous studies [29-33].

\section{Electrochemical detection setup}

The experimental setup is shown in Fig. 1. A threeelectrode system was employed, with a nano materialfunctionalised glass carbon electrode (GCE) as a working electrode (WE), an $\mathrm{Hg} / \mathrm{HgCl}_{2} / \mathrm{KCl}$ electrode as a reference electrode (RE) and a platinum wire as a counter-electrode (CE). To avoid interference from direct UV irradiation of the electrodes, the electrodes were assembled on the side-wall of the detection well. In addition, a piece of aluminium foil with a hole was placed on top of the detection well to confine the UV light to impacting only on the cells. Electrochemical detection was carried out with an electrochemical station (CHI 760e, Chen Hua Instruments Co. Ltd., China).

\section{Electrochemical detection of $\mathrm{O}_{2}{ }^{--}$released by the cells Preparation of an $\mathrm{O}_{2}^{--}$electrochemical sensor}

The construction of electrochemical sensor for $\mathrm{O}_{2}{ }^{\cdot-}$ detection was detailed in our recent paper [34, 35]. In brief, single stranded DNA (2.1 $\mathrm{mg})$ was added to $\mathrm{MnSO}_{4}(1.0 \mathrm{~mL}, 0.10 \mathrm{M})$ under constant stirring at $60^{\circ}$ Cstirring until the solution became transparent. The pellet of DNA-Mn $\mathrm{M}_{3}\left(\mathrm{PO}_{4}\right)_{2}$ composite was recovered by centrifugation. To prepare the $\mathrm{O}_{2}{ }^{--}$sensing electrode, carbon nanotube (CNT, $0.5 \mathrm{mg} \mathrm{mL}^{-1}$ ) and DNA- DNA$\mathrm{Mn}_{3}\left(\mathrm{PO}_{4}\right)_{2}(0.20 \mathrm{M})$ were drop-casted on a polished glass-carbon electrode. To detect $\mathrm{O}_{2}{ }^{\cdot-}$, electrodes modified with CNT@DNA- $\mathrm{Mn}_{3}\left(\mathrm{PO}_{4}\right)_{2}$ composite were exposed to aliquots of $\mathrm{KO}_{2}$ and cyclic voltammetry curves were recorded. The peak current value at $0.70 \mathrm{~V}$ was recorded and was plotted against the concentration of $\mathrm{KO}_{2}$ to draw a current-dose calibration curve.

\section{In situ detection of production of $\mathrm{O}_{2}{ }^{--}$from UV-irradiated cells}

Confluent A375 cells were seeded into 24 cell plates, at a density of $1 \times 10^{5}$ per well, and were incubated for $6 \mathrm{~h}$. Then $\alpha$-tocopherol $(25 \mu \mathrm{M}$ was chosen due to optimize concentration [33]) was added into cells and incubated for another $12 \mathrm{~h}$. The cell-culture disc with adherent cells was transferred to the electrochemical detection cell (Fig. 1), to which serum free medium $(2.5 \mathrm{~mL})$ was added. Then the cells were exposed to UVR and the electrochemical signal arising from $\mathrm{O}_{2}{ }^{\cdot-}$ were recorded by $\mathrm{CHI}$. Cells without anti-oxidant were measured with the same schedule as controls.

\section{Fluorescent staining of oxygen radicals Intracellular ROS}

A375 cells were collected and seeded at a density of $1 \times$ $10^{5}$ per well in 24-well plates and were incubated overnight with or without $\alpha$-tocopherol. Intracellular

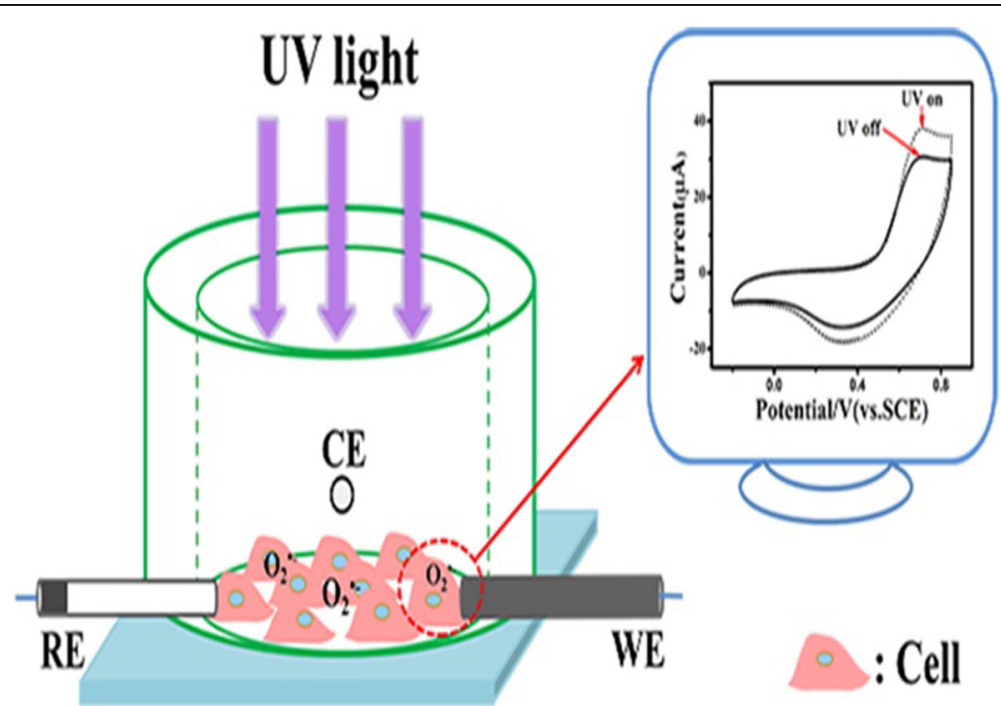

Fig. 1 Electrochemical sensor for quantifying generation of superoxide anion $\left(\mathrm{O}_{2}{ }^{-}\right)$from cells during UV irradiation. UV: ultraviolet; RE: reference electrode; CE: counter electrodes; WE: working electrode 
generation of ROS upon UV irradiation was determined with a DCFH-DA $(10 \mathrm{mM})$ assay kit (Beyotime Inc. S0033). In brief, following UVA irradiation, cells are washed twice in phosphate buffer saline (PBS) and allowed to incubate in $10 \mu \mathrm{M} / \mathrm{L}$ DCFH-DA (1:1000 dilution in PBS) at $37^{\circ} \mathrm{C}$ for 20 min according to the manufacturer's instructions (Beyotime Inc.). The excess DCFH-DA was rinsed off with phosphate buffer saline (PBS) $(1.0 \mathrm{mM})$. The cells were then observed and imaged under a fluorescence microscope (IX-71, Olympus Corp., Tokyo, Japan).

\section{$\mathrm{O}_{2} \cdot{ }^{--}$colorimetric assay kit}

Superoxide assay kit (S-0060 Beyotime Biotechnology Beijing Inc.) was conducted following the product instructions. In brief, A375 cells were seeded $\left(1 \times 10^{4}\right)$ in 96-well plates and $80-90 \%$ confluence when treated. Now the cells were washed three times in PBS, and allowed to incubate in $10 \mu \mathrm{mol} / \mathrm{L}$ DCFH-DA (1:1000 dilution) at $37{ }^{\circ} \mathrm{C}$ for $3 \mathrm{~min}$ (Beyotime Biotechnology, Beijing Inc.). The excess DCFH-DA was rinsed off with PBS $(1.0 \mathrm{mM})$. Now the cells were irradiated with respective UVR (UV, UVA or UVB) stimulus. Prepare the three wells without irradiation should be used as a blank control. Select 2 wells to add 2\% SOD (Beyotime Biotechnology, Beijing Inc.) in the wells of the stimulus to verify the entire assay system. The cells were then observed and imaged under a fluorescence microscope (IX71, Olympus Corp., Tokyo, Japan).The absorbance values taken at $450 \mathrm{~nm}$ were compared with the reference absorbance values at $630 \mathrm{~nm}$ following to manufacturer's instructions. These data were expressed as the percentage of increase of absorbance value compared to sham controls (sham-irradiated groups).

\section{Cell viability assay}

The protective effects of $\alpha$-tocopherol on UVirradiated melanoma cell A375 were evaluated using the MTT assay. In brief, cells were seeded at a density of $1 \times 10^{4}$ per well in 96-well plates and incubated with or without the $\alpha$-tocopherol for $12 \mathrm{~h}$. Following challenge with UVR, the cells were cultured in conditional culture medium for a further $24 \mathrm{~h}$. Each well then received $10 \mu \mathrm{L}$ of MTT solution $\left(0.5 \mathrm{mg} \mathrm{mL}^{-1}\right)$ and were incubated for $3-4 \mathrm{~h}$ at $37{ }^{\circ} \mathrm{C}$. Then $100 \mu$ Llysisbuffer (mixture of 2-propanol, Triton-100 and hydrochloric acid) was added to each well to dissolve the purple-coloured formazan produced by viable cells, before colorimetric analysis. The absorbance at $570 \mathrm{~nm}$ was measured by a microplate reader and the results were expressed as the percentage of surviving cells compared to the shamirradiated vehicle control group.

\section{Statistical analysis}

Results are expressed as means \pm standard error of the mean (SEM). The data were analysed by Student's t-test using Origin Statistic software (Origin Lab Corporation, USA). $P<0.05$ was considered significant. All experiments were performed three independent times in triplicates.

\section{Results and discussion \\ Quantification of UV-inducedO $\mathrm{O}_{2}{ }^{--}$in melanoma cells by label-free electrochemical sensor}

To evaluate the feasibility of using an electrochemical method to quantify production of $\mathrm{O}_{2}{ }^{-{ }^{-}}$induced by UV irradiation from melanoma cells, an electrochemical sensor was fabricated and characterised. Initially, cyclic voltammetry $(\mathrm{CV})$ was performed with $\mathrm{PBS}$ to characterize the CNT@DNA- $\mathrm{Mn}_{3}\left(\mathrm{PO}_{4}\right)_{2}$ functionalised electrochemical sensor. $\mathrm{KO}_{2}$ was used as the source of $\mathrm{O}_{2}{ }^{{ }^{-}}$as reported in literature [19]. The peak current of the oxidative state/stress at $0.7 \mathrm{~V}$ increases when $\mathrm{KO}_{2}$ was added to PBS (blue line inset of Fig. 2a). The production of superoxide anions $\left(\mathrm{O}_{2}{ }^{-}\right)$is linked with diverse range of biochemical phenomenon leading to various oxidative stress mediated pathologies. The electrochemical determination of superoxide ion is solely depending on SOD enzyme, hence check it's reproducibility as well as not a cost effective, and advancement in nanosciences solved certain limitations with this procedure. Previously we demonstrated that $\mathrm{Mn}_{3}\left(\mathrm{PO}_{4}\right)_{2}$ nanosheets which are a biomimetic enzyme were template-synthesized with DNA and further assembled on carbon nanotubes (CNTs) that form nanocomposite sheets (DNA-Mn $\left.{ }_{3}\left(\mathrm{PO}_{4}\right)_{2}-\mathrm{CNT}\right)$ [34]. The dismutation of superoxide ion was catalyzed by $\mathrm{Mn}_{3}\left(\mathrm{PO}_{4}\right)_{2}$ sheets, but the CNTs allows quick shifts of electrons to maximize its sensitivity, specificity and reproducibility for $\mathrm{O}_{2}{ }^{--}$detection [34].

The increased peak current gradually decreased to PBS level after the introduction of SOD to decompose/ neutralize $\mathrm{O}_{2}{ }^{-{ }^{-}}$(red line inset of Fig. 2a). Different concentrations of $\mathrm{KO}_{2}$ were added to vary the amount of $\mathrm{O}_{2}{ }^{--}$and the peak current at $0.7 \mathrm{~V}$ was recorded that was plotted against the concentration of $\mathrm{O}_{2}{ }^{*-}$. The corresponding calibration curve of current response vs. $\mathrm{O}_{2}{ }^{-}$concentration showed a sensitivity of $70 \mathrm{nA} \mathrm{nM}-1$ (Fig. 2b).The $\mathrm{CV}$ curves showed that, the change in current $(\mu \mathrm{A})$ is associated with changing in the production of $\mathrm{O}_{2}{ }^{--}$at different $\mathrm{UV}$ treatments (UV, UVA, UVB) and in sham-irradiated control (Fig. 2c). Furthermore, to verify the electrochemical-sensing efficacy, the $\mathrm{O}_{2}{ }^{\cdot-}$ assay kit was used to measure $\mathrm{O}_{2}{ }^{\cdot-}$ generated from melanoma cells challenged with UVR; a similar increase was observed in both methods. Incubation of cells with SOD eliminatesincreased ${ }_{2}{ }^{\cdot-}$ in 

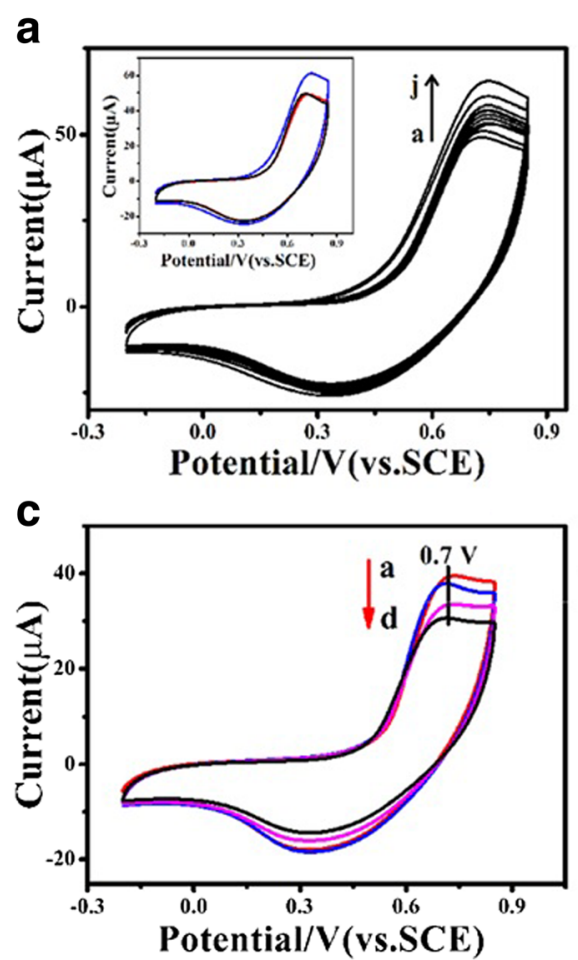

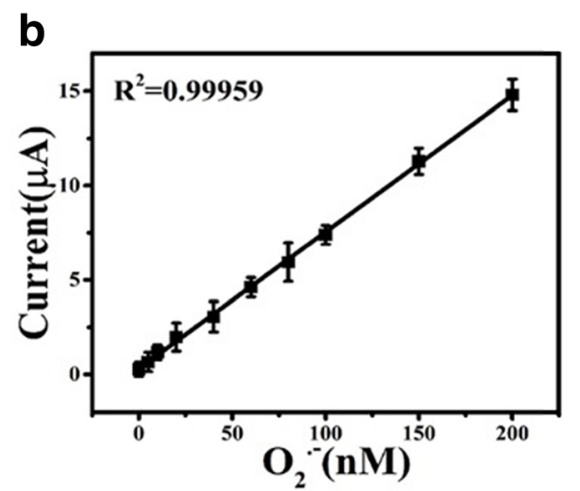

d

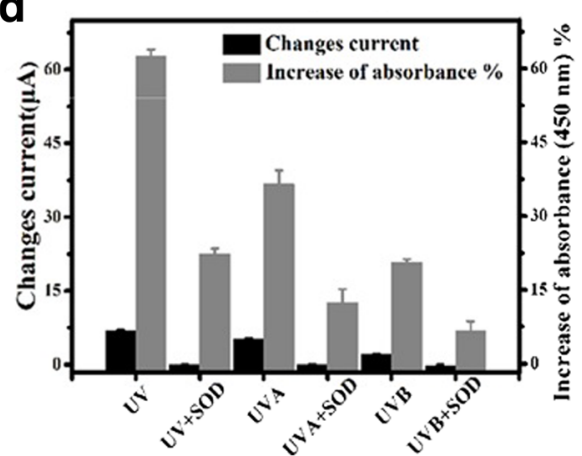

Fig. 2 Calibration of CNT@DNA-Mn $\left(\mathrm{PO}_{4}\right)_{2}$ modified glass-carbon electrode for measurement of $\mathrm{O}_{2}{ }^{--}$and electrochemical characterization of $\mathrm{O}_{2}{ }^{--}$ released by cells following UVR irradiation. a Cyclic voltammetry (CV) curves measured with PBS and PBS plus different concentrations of $\mathrm{KO}_{2}$ (nM). a: 0, b: 5, c: 10, d: 20, e: 40, f: 60, g: 80, h: 100, i: 150, j: 200; inset: CV curves measured with PBS (black), PBS plus KO ${ }_{2}(150$ nM, blue), and KO 2

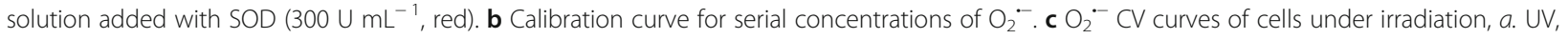
b. UVA, c. UVB, d. Sham-irradiation control. d Histogram of peak current changes compared to sham-irradiated cells (black column, $n=3$ ) and generation of $\mathrm{O}_{2}^{-{ }^{-}}$upon irradiation with UV as quantified by the $\mathrm{O}_{2}^{-{ }^{-}}$assay kit: increase of absorbance at $450 \mathrm{~nm}$ (grey column, $\mathrm{n}=3$ ). SOD: superoxide dismutase. UV $\left(10.5 \mathrm{~J} \mathrm{~cm}^{-2}=105 \mathrm{~kJ} \mathrm{~m}^{-2}\right)$, UVA $\left(10 \mathrm{~J} \mathrm{~cm}^{-2}=100 \mathrm{~kJ} \mathrm{~m}^{-2}\right)$, UVB $\left(0.5 \mathrm{~J} \mathrm{~cm}^{-2}=5 \mathrm{~kJ} \mathrm{~m}^{-2}\right)$

the culture medium, while the electrochemical sensing measures a similar pattern of generation of UVRinduced $\mathrm{O}_{2}{ }^{-}$as did conventional fluorescent staining for $\mathrm{O}_{2}{ }^{--}$(Fig. 2d), the former with less consumption of sample and shorter experimental time. These suggested that, the electrochemical sensor provides a possibility of recording production of $\mathrm{O}_{2}{ }^{--}$in groups of A-375 cells facing different doses of UVR, without disturbing the cellular metabolism.

\section{Measurement of UV-irradiation induced $\mathrm{O}_{2}{ }^{--}$and its diminution with a-tocopherol by using label-free electrochemical sensor}

To demonstrate the feasibility of electrochemical sensor as an analytical tool to evaluate the anti-oxidative capability of compounds, we pre-treated UVRchallenged cells with an antioxidant compound ( $\alpha$ tocopherol). The electrochemical sensor was used for direct measurement of $\mathrm{O}_{2}{ }^{\cdot-}$ generated from A375 cells pre-treated with $\alpha$-tocopherol followed UV irradiation. In addition free-radical-scavenging effects of the antioxidant $\alpha$-tocopherol in A375 cells given UVA, UVB and bulk UV were also investigated with the same electrochemical sensor. For this purpose, the normalized current change at $0.7 \mathrm{~V}$ was calculated in sham-irradiated cells as a control by using following equation.

$$
\Delta \text { Current } \%=[(\mathbf{C i}-\mathbf{C 0}) / \mathrm{C} 0] \times \mathbf{1 0 0} \%
$$

Where $\mathrm{Ci}$ is current value measured upon UV irradiation, $\mathrm{CO}$ is current value of sham control (shamirradiated).

The $\Delta$ Current $\%$ was plotted against irradiation energy dose of UV fractions. A higher change in current indicated a higher generation of $\mathrm{O}_{2}{ }^{\cdot-}$ when compared with sham-irradiated control. The changes of production of $\mathrm{O}_{2}{ }^{--}$in melanoma A375 cells irradiated with UVs (UV, UVA, UVB) was comparatively measured by the electrochemical sensor (Fig. 3a-c). Different UV doses $\left(0-105 \mathrm{~kJ} \mathrm{~m}^{-2}\right)$ induced the production of $\mathrm{O}_{2}{ }^{\cdot-}$, that altered the currents by $13.1 \%\left(50 \mathrm{~kJ} \mathrm{~m}^{-2}\right)$ to that of the sham. Tocopherol $(25 \mu \mathrm{M})$ treatment to UV-challenged cells reduces the production of $\mathrm{O}_{2}{ }^{-{ }^{-}}$to $8.2 \%$ $\left(50.25 \mathrm{~kJ} \mathrm{~m}^{-2}\right)$ when compared to UVs-irradiation only (Fig. 3a). Similarly, pre-treatment of cells with 
$\mathbf{a}$

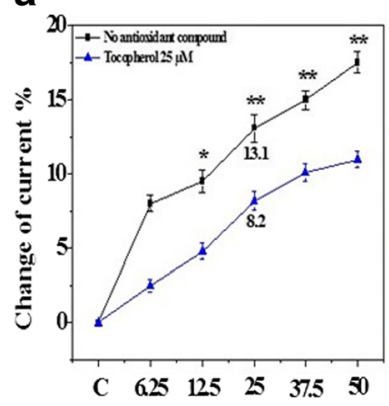

d

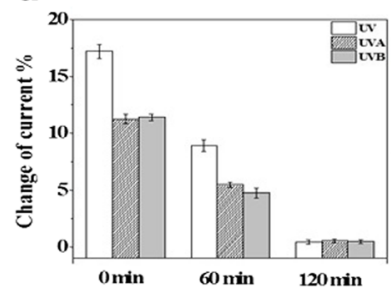

b

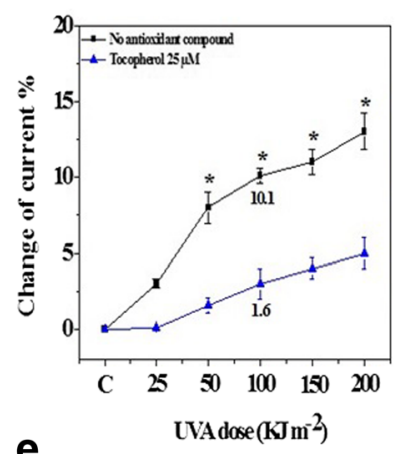

e

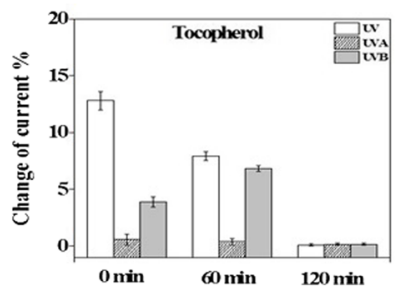

C

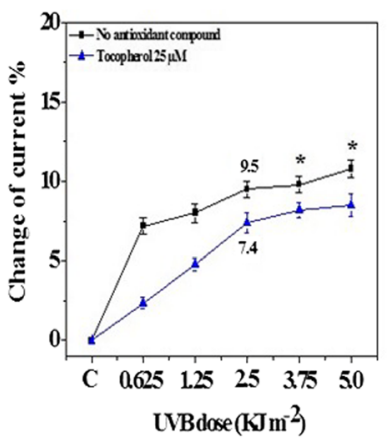

Fig. 3 a-c Extracellular $\mathrm{O}_{2}{ }^{--}$quantified by electrochemical method in melanoma A375 cells. A375 cells were exposed to UV (A), UVA (b) and UVB (c); Non-pretreatment: black line; $a$-tocopherol pre-treatment: blue line. $\mathrm{O}_{2}{ }^{--}$generation during post-UVs irradiation quantified by electrochemical sensing: non-treatment (d) a-tocopherol pretreatment $(\mathbf{e})(n=3)$, ${ }^{*}$ denotes $P<0.05$, ${ }^{* *}$ denotes $P<0.01$

tocopherol efficiently decreased (8.5\%) the production of $\mathrm{O}_{2}{ }^{\cdot-}$ induced by a UVA $\left(100 \mathrm{~kJ} \mathrm{~m}^{-2}\right)$ dose to $1.6 \%$ compared to sham (Fig. 3b). In contrast, pre-treatment of cells with $\alpha$-tocopherol followed by UVB irradiation, showed little effects on the production of $\mathrm{O}_{2}{ }^{--}$(Fig. 3c).

The electrochemical sensor is not only able to quantify the generation of $\mathrm{O}_{2}{ }^{\cdot-}$ at acute phase following UVirradiation, but also enabled quantification at post-UVR challenge period. After $60 \mathrm{~min}$. Following UVR, in melanoma A375 cells $\mathrm{O}_{2}{ }^{-}$generated current was decreased to half $(8.5 \%)$ than at zero time point $(17 \%)$, while at $120 \mathrm{~min}$. The change in electric current faded to the background level (Fig. 3d).

The effect of $\mathrm{UV}$ on $\mathrm{O}_{2}{ }^{--}$production are not the sum of the total effects of UVA and UVB, the production of $\mathrm{O}_{2}{ }^{\cdot-}$ from cells challenged by various UV doses (0$105 \mathrm{~kJ} \mathrm{~m}^{-2}$, Fig. 3a) is lower than the sum of changes induced by UVA (Fig. 3b) plus UVB (Fig. 3c). Next, we found that $\alpha$-tocopherol plays a distinct role and lessen the generation of $\mathrm{O}_{2}{ }^{--}$in pre-treated $\mathrm{A} 375$ cells followed by UV irradiation, however, UVA and UVB showed different capacities to trigger the generation of $\mathrm{O}_{2}{ }^{-}$in melanoma A-375 cells.

The pre-treatment of $\alpha$-tocopherol reduced the UVA and UVB induced $\mathrm{O}_{2}{ }^{--}$generation by almost $85 \%$ and $20 \%$, respectively (Fig. 3b,c). This difference may due to the generation of $\mathrm{H}_{2} \mathrm{O}_{2}$, or interference of some other unknown reason yet, hence need further optimisation of the method. Furthermore, antioxidant tocopherol showed different behaviour against UVA and UVB induced $\mathrm{O}_{2}{ }^{\cdot-}$ is due to the difference in wavelength energy. In addition to variable UV wavelength effects, antioxidants are distinct chemical units with different modes of action for their effects and possess a unique biochemical profile hence making it different from other related compounds. Based on the results of electrochemical sensor, we speculated that $\alpha$-tocopherol showed different protective properties in melanoma cells exposed to different UV wavelengths. In general, the electrochemical sensor is able to characterize the $\mathrm{O}_{2}{ }^{--}$ production, as cellular oxidative status is one of the indicators.

\section{Prediction of protective effect of a-tocopherol on cell survival through electrochemical sensing}

To analyse the effect of $\alpha$-tocopherol on cell survival following UVR, A375 cells were exposed to different doses of UV, UVA and UVB, and the anti-oxidant effect of $\alpha$ tocopherol was assessed by calculating the cell survival rate by using following equation.

$$
\text { Cell survival } \%=\left[\left(\mathrm{A}_{\mathrm{T}}-\mathrm{Ac}\right) / \mathrm{Ac}\right] \times 100 \%
$$

Where $A_{T}$ is the absorbance value of UV-irradiated cells and Ac is absorbance value of sham-irradiated cells. This calculation, gives survival of cells under UV irradiation is normalized to the sham or control cells. The $\alpha$-tocopherol had significant cytoprotective effects on melanoma A375 cells, and it enhanced cell survival (18\%) following UV light exposure $\left(50.25 \mathrm{~kJ} \mathrm{~m}^{-2}=\right.$ UVA $50 \mathrm{~kJ} \mathrm{~m}^{-2}+$ UVB 0 . 

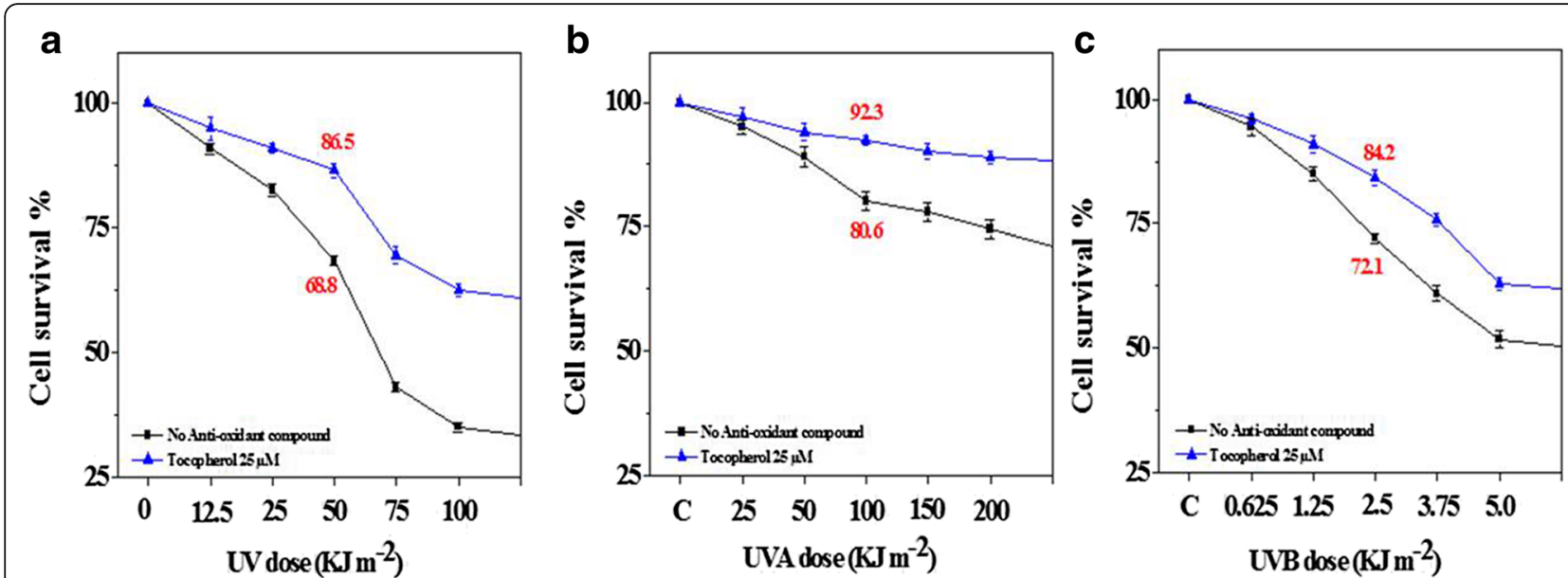

Fig. 4 Survival of cells pre-treated by a-tocopherol under UV irradiation with melanoma A375 cells. These survival rates were calculated using sham-irradiated cell as reference, $(n=3)$. (a) UV dose $(50 \mathrm{~kJ} \mathrm{m-2)}$ decreases cell survival to $68.8 \%$ with a-tocopherol recurrence of $86.5 \%$ cell viability. (b) Equivalent UVA dose (100 kJ m-2) gave cell viability loss to $80.6 \%$ which is recovered by a-tocopherol to $92.3 \%$ cell viability. (c) Finally the equivalent UVB dose (2.5 kJ m-2) given cell viability of $72.1 \%$ that finally recovered by a-tocopherol to $84.2 \%$ viable cells. Non-pretreatment: black line; a-tocopherol pre-treatment: blue line

$25 \mathrm{~kJ} \mathrm{~m}^{-2}$ ) (Fig. 4a). During studies of UVA-induced cell damage, $\alpha$-tocopherol appeared to be more cytoprotective as indicated by the survival rates of pre-treated (92.3\%) compared with control melanoma A375 cells (80\%), with $10 \%$ marked and significant difference in reduction of cell survival (Fig. 4b). On the other hand, UVB induced cell viability loss (72\%) was significantly repaired by $\alpha$ tocopherol pre-treatment (84\%) compared with control, with $12 \%$ of protection revival (Fig. $4 \mathrm{c}$ ).

Collectively, MTT cell-survival assay showed that $\alpha$ tocopherol is effective in diminishing UV, UVA and UVBinduced damage in melanoma A375 cells, this is similar to results given by electrochemical sensing and colorimetric assay for $\mathrm{O}_{2}{ }^{\cdot-}$ levels (Fig. 3a-e). Interpreting the survival rate (Fig. 4a-c) of cells pre-treated with $\alpha$-tocopherol followed by UV irradiation caused the generation of $\mathrm{O}_{2}{ }^{\cdot-}$ (Fig. 3a-c) may efficiently harbour the oxidative stress and lessen it promptly. The different cytoprotective efficacy of $\alpha$-tocopherol against UVA- or UVB-induced cell death was decreased, thus could be specified as the distinct capability of $\alpha$-tocopherol to eliminate UV fraction induced oxidative stress, since UVA is the major oxidative stress causing wavelength in UV.

\section{Comparison of methodologies towards UV-induced cellular oxidative stress}

The MTT assay was conducted to evaluate the loss of viability induced by UV irradiation. It monitors the overall cell growth over a period of time, thus showing its strength in evaluating the long-term effect of a treatment on cells [34, 35]. A large body of work, spanning more than four decades, demonstrates fluorescent probe labelling for characterisation of changes of intracellular ROS [36, 37].

However, it is also clear that this probe-labelling method measures transient fluxes of oxidants only with great difficulty $[38,39]$. Most importantly, the labelling of cells challenges the possibility to characterize the changes in situ of cells during a time period in responding to a treatment. The merits of label-free

Table 1 Comparison of methods used to study effect of UV irradiation induced oxidative stress

\begin{tabular}{llll} 
& MTT assay & Fluorescent assay & Electrochemical detection \\
\hline Labeling & Yes & Yes & No \\
Real time & NO & NO & Yes \\
Sample consumption & Large & Large & Small
\end{tabular}

Assay time 24-72 h

Overall comparison Alive cell catalyse enzyme to indirectly characterize cell growth.

Evaluate the overall effect of treatment on cell survival, growth.
$1-2 \mathrm{~h}$

Fluorophore probe is used to label target molecules. Not feasibly for real-time characterizing a reaction. Staining process will affect the health of cells.
Within minutes

In site characterize a reaction. No damage to cells.

Fast reaction time allows for high throughput screening. No expensive equipment is involved. 


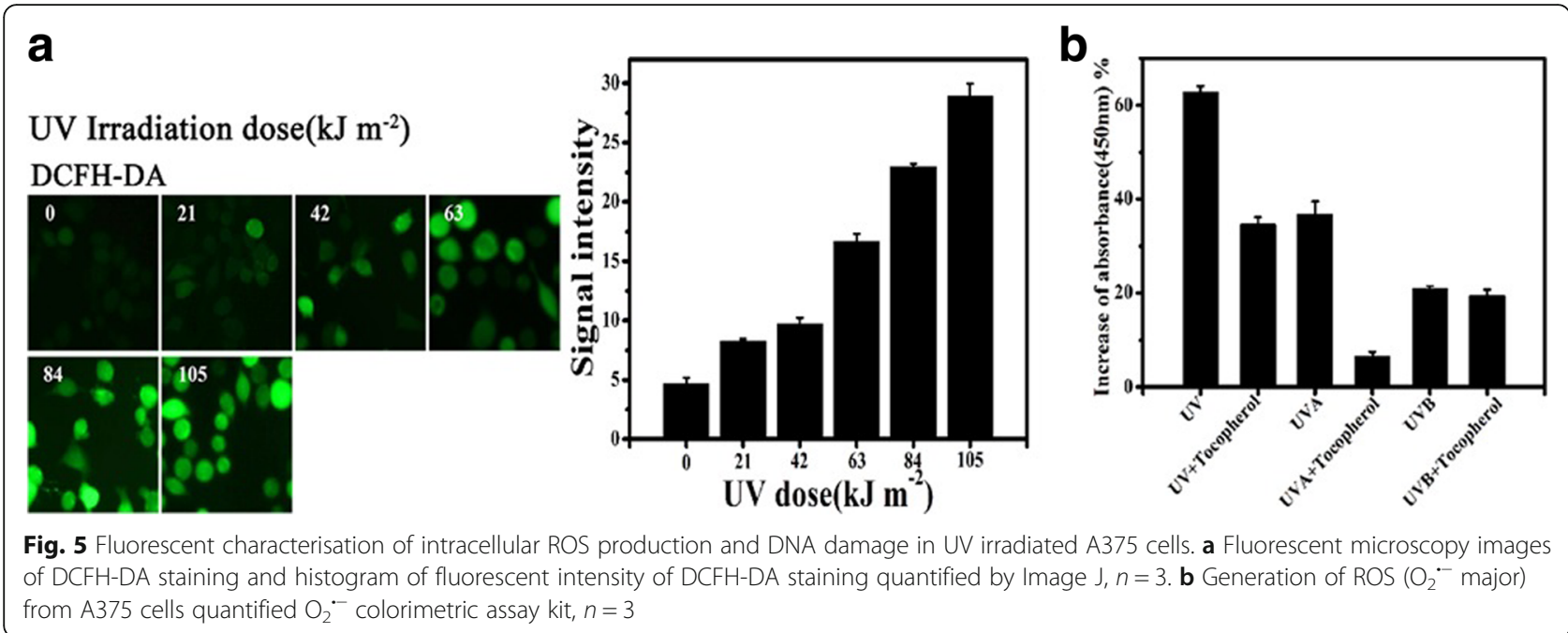

electrochemical sensing have been discussed in the literature $[27,34,40]$ (Table 1). To confirm the feasibility of electrochemical sensing as an analytical tool to determine the anti-oxidative capability of unknown compounds, we performed conventional $\mathrm{O}_{2}{ }^{{ }^{-}}$fluorescent staining with a standard DCFH-DA fluorescent staining protocol that measures intracellular ROS from cells after exposure to UV light. It is clear from the results that UV irradiation can induce an increase of the intensity of the signal for green fluorescence. Figure $5 \mathrm{a}$ presents the quantitative changes of $\operatorname{ROS}\left(\mathrm{O}_{2}{ }^{\cdot-}\right)$ measured by fluorescent staining of three independent methods. The fluorescence signal is gradually increased in response to increasing UV dose and the maximum signal is given by cells irradiated with $105 \mathrm{~kJ} \mathrm{~m}^{-2} \mathrm{UV}$ light. Increases of intracellular ROS following UV irradiation visualized in this study are well in line with previously reported studies $[17,23]$ and our present electrochemical sensing results. Further increase of UV energy $\left(21 \mathrm{~J} \mathrm{~cm}^{-2}=\right.$ $210 \mathrm{~kJ} \mathrm{~m}^{-2}$ ) does not give further increased ROS fluorescence signal, perhaps due to significant cell death (Data no shown).

The protective efficacy of anti-oxidant $\alpha$-tocopherol was assessed and much attention was paid to the UV dose of $105 \mathrm{~kJ} \mathrm{~m}^{-2}$, i.e. [UVA $\left(10 \mathrm{~J} \mathrm{~cm}^{-2}\right)+\mathrm{UVB}(0$. $\left.\left.5 \mathrm{~J} \mathrm{~cm}^{-2}\right)\right]$. The $\mathrm{O}_{2}{ }^{\circ-}$ assay kit was used to measure the colorimetric changes induced by $\mathrm{O}_{2}{ }^{\cdot-}$ in a 96-well plate experimental setting. The results showed that the antioxidant can reduce the generation of $\mathrm{O}_{2}{ }^{--}$induced by UV in A375 cells. Different anti-oxidation efficacies of the model anti-oxidant are observed in melanoma A375 cells against UVA and UVB exposure (Fig. 5b). It is encouraging to see that standard labelling techniques and electrochemical quantification depict a response pattern of UV irradiation and the anti-oxidant effects of $\alpha$ tocopherol which are well correlated. In addition, electrochemical sensing revealed the oxidation status, which can be used to predict UV-induced ROS efflux and ultimately cell damage. The fast and easy experimental procedures permitted us to test the efficacy of anti-oxidant $\alpha$-tocopherol against UVA and UVB in melanoma cells $[33,40]$. We demonstrate the potential of electrochemical methods for high throughput screening of potential anti-oxidant compounds, although further improvements in the signal-to-noise ratio are needed. We believe that electrochemical sensing would be a potent and economical candidate to provide meaningful complementary information for standard fluorescent staining experiments.

\section{Conclusions}

The results showed, in melanoma A375 cells electrochemical sensing both UVA and UVB -induced production of ROS e.g. $\mathrm{O}_{2}{ }^{--}$. The potential use of in UV (UV, UVA, UVB) involved biological research is enhanced, since the electrochemical sensor quantified $\mathrm{O}_{2}{ }^{\cdot-}$ levels in medium could be correlated with the cell survival ability under the protection of anti-oxidant $\alpha$-tocopherol as well. The electrochemical changes occurred with $\mathrm{O}_{2}{ }^{\cdot-}$ production, can be seen with this label-free method correlated with intracellular fluorescent staining as well. It highlighted the potential of the electrochemical method for high-throughput screening of anti-oxidant under UV irradiation, and for investigation of their related mechanisms.

\section{Abbreviations}

DCFH-DA: 2',7'-dichlorodihydrofluorescein diacetate; $\mathrm{H}_{2} \mathrm{O}_{2}$ : Hydrogen peroxide; $\mathrm{kJ} \mathrm{m}^{-2}$ : Kilo Jouls per square meter; MTT: 3-[4,5-Dimethylthiazol-2yl]-2,5-diphenyltetrazolium bromide; $\mathrm{O}^{--}$: Superoxide anion; ROS: Reactive oxygen species; SOD: Superoxide dismutase; UVA: Ultraviolet A; UVB: Ultraviolet B; UVR: Ultraviolet radiation 


\section{Acknowledgements}

We thank Prof. Rex M. Tyrrell and Prof. Threadgill (The University of Bath, UK) for useful discussion.

\section{Funding}

This work is financially supported by Chongqing Key Laboratory for Advanced Materials and Technologies of Clean Energies (Chongqing, China), the National Science Foundation of China (No. 31200700, 21375108, 81271776 and81573073). Open funding, Chongqing Municipal Key laboratory of oral diseases and biomedical sciences, Biomedical Engineering of Higher Education. None of the projects are in a financial or personal relationship to this study.

\section{Availability of data and materials}

No additional data is linked with these findings. Moreover, in any query please contact author for data requests.

\section{Authors' contributions}

LG and CB performed the experiments and most of the lab work. MFN, SC, $Y L, C M L$, and JLZ designed the study and experimental procedures and statistical analyses. PJ, EH, MFN and JLZ drafted this study to a final form. All authors read and approved the final mansucript.

\section{Ethics approval and consent to participate} Not applicable.

\section{Consent for publication}

All the authors mentioned in the author section, agreed to submit this paper for publication in Journal of Biological Engineering, and have no dispute for this submission and publication. None of the authors declare any conflict of interest.

\section{Competing interests}

The authors declare no any competing interests regarding the submission and publication of this article in Journal of Biological Engineering.

\section{Publisher's Note}

Springer Nature remains neutral with regard to jurisdictional claims in published maps and institutional affiliations.

\section{Author details}

${ }^{1}$ College of Bioengineering \& School of Life Sciences, Chongqing University, Chongqing 400044, China. ${ }^{2}$ Institute for Clean Energy \& Advanced Materials, Faculty of Materials \& Energy, Southwest University, Chongqing 400715, China. ${ }^{3}$ Chongqing Municipal Key laboratory of oral diseases and biomedical sciences, Biomedical Engineering of Higher Education, Chongqing 401147, China. ${ }^{4}$ Interdisciplinary Research Centre in Biomedical Materials (IRCBM), COMSATS University Islamabad, Lahore Campus, Lahore 54000, Pakistan.

\section{Received: 12 October 2017 Accepted: 23 April 2018}

\section{Published online: 12 September 2018}

\section{References}

1. Tyrrell RM. Modulation of gene expression by the oxidative stress generated in human skin cells by UVA radiation and the restoration of redox homeostasis. Photochem Photobiol Sci. 2012;11:135-47.

2. Godar DEUV doses worldwide. Photochem Photobiol. 2005:81:736-49.

3. Liebel F, Kaur S, Ruvolo E, Kollias N, Southall MD. Irradiation of skin with visible light induces reactive oxygen species andmatrix-degrading enzymes. J Invest Dermatol. 2012;132:1901-7.

4. Armstrong BK, Kricker A. The epidemiology of UV induced skincancer. J Photochem Photobiol B. 2001;63:8-18

5. Dizdaroglu M, Jaruga $P$, Birincioglu $M$, Rodriguez $H$. Free radical-induced damage to DNA: mechanisms and measurementFree. RadBiol Med. 2002;32: 1102-15.

6. Zhang Y, Mattjus P, Schmid PC, Dong Z, Zhong S, Ma WY, Brown RE, Bode AM, Schmid HH, Dong Z. Involvement of the acid sphingomyelinasepathway in UVA-induced apoptosis. J Biol Chem. 2001; 276:11775-82.

7. Berwick M, Lachiewicz A, Pestak C, Thomas N. Solar UV exposure and mortality from skin tumors. Advanc Experiment Med Biol. 2008;624:117-24.
8. Tyrrell RM, Pidoux M. Singlet oxygen involvement in the inactivation of cultured human fibroblasts by UVA (334 nm, $365 \mathrm{~nm}$ ) and near-visible (405 $\mathrm{nm}$ ) radiations. Photochem Photobiol. 1998:49:407-12.

9. Duthie MS, Kimber I, Dearman RJ, Norval M. Differential effects of UVA1 and UVB radiation on Langerhans cell migration in mice. J Photochem Photobiol B. 2000:57:123-31.

10. Herrling $T$, Jung $K$, Fuchs J. Measurements of UV-generated free radicals/ reactive oxygen species (ROS) in skin. Spectrochim Acta Part A. 2006;63: $840-5$

11. Krutmann J. The interaction of UVA and UVB wavebands with particular emphasis on signalling. Prog Biophys Mol Biol. 2006;92:105-7.

12. Syed DN, Afaq F, Mukhtar H. Differential activation of signalling pathways by UVA and UVB radiation in normal human epidermalkeratinocytes. Photochem Photobiol. 2012;88:1184-90

13. Petersen AB, Gniadecki R, Vicanova J, Thorn T, Wulf HC. Hydrogen peroxide is responsible for UVA-induced DNA damage measured by alkaline comet assay in HaCaT keratinocytes. J Photochem Photobiol B. 2000;59:123-31.

14. Wolfle U, EsserPR S-HB, Martin SF, Lademann J, Schempp CM. UVB-induced DNA damage, generation of reactive oxygen species, and inflammation are effectively attenuated by the flavonoid luteolinin vitro and in vivo. Free Rad Biol Med. 2011:50:1081-93.

15. Yasui H, Hakozaki T, Date A, Yoshii T, Sakurai H. Real-time chemiluminescent imaging and detection of reactive oxygen species generated in the UVB-exposed human skin equivalent model. Biochem Biophys Res Comm. 2006:347:83-8.

16. Peus $D$, Vasa RA, Meves $A$, Pott M, Beyerle A, Squillace $K$, Pittelkow MR. $\mathrm{H}_{2} \mathrm{O}_{2}$ is an important mediator of UVB-inducedEGF-receptor phosphorylation in cultured keratinocytes. J Invest Dermat. 1998;110:966-71.

17. Rezvani HR, Mazurier F, Cario-Andre M, Pain C, Ged C, Taieb A, de Verneuil $H$. Protective effects of catalase overexpression on UVB-induced apoptosis in normal human keratinocytes. J Biolog Chem. 2006:281:17999-8007.

18. Fridovich I. Superoxide anion radical $\left(\mathrm{O}_{2}{ }^{-}\right)$, superoxide dismutases, and relatedmatters. J Biol Chem. 1997;272:18515-7.

19. Komarov DA, Slepneva IA, Glupov W, Khramtsov W. Superoxide and hydrogen peroxide formation during enzymatic oxidation of DOPA by phenoloxidase. Free Rad Res. 2005;39:853-8.

20. Li XR, Wang B, Xu JJ, Chen HY. In vitro detection of superoxide anions released from cancer cells based on potassium-dopedcarbon nanotubes ionicliquid composite gels. Nanoscale. 2011:3:5026-33.

21. Suschek CV, Mahotka C, Schnorr O, Kolb-BachofenV. UVB radiation-mediated expression of inducible nitric oxide synthase activity and the augmenting role of co-induced TNF-alpha in human skin endothelial cells. J Invest Dermat. 2004;123:950-7.

22. Lee ER, Kim JH, Kang YJ, Cho SG. The anti-apoptotic and anti-oxidant effect of eriodictyol on UV-induced apoptosis in keratinocytes. Biolog Pharm Bull. 2007:30:32-7.

23. Tada M, Kohno M, Niwano Y. Scavenging or quenching effect of melanin on superoxide anion and singlet oxygen. J ClinBiochemNutrit. 2010:46:224-8.

24. Grange PA, Chereau C, Raingeaud J, Nicco C, Weill B, Dupin N, Batteux F. Production of superoxide anions by keratinocytes initiates $P$ acnes-induced inflammation of the skin. PLoS Pathog. 2009;5:e1000527.

25. Korshunov S, Imlay JA. Detection and quantification of superoxide formed within the periplasm of Escherichia coli. J Bacter. 2006;188:6326-34.

26. Herrling $T$, Zastrow L, Fuchs J, Groth N. Electron spin resonance detection of UVA-induced free radicals. Skin Pharm ApplSkin Physiol. 2002;15:381-3.

27. Shi ZZ, Wu XS, Gao LX, Tian YL, Yu L. Electrodes/paper sandwich devices for in situ sensing of hydrogen peroxide secretion from cells growing in gelsin-paper 3 dimensional matrix. Analyt Methods. 2014;6:4446-54.

28. Balasaraswathy $P$, Kumar U, Srinivas CR, Nair S. UVA and UVB in sunlight, optimal utilization of UV rays in sunlight for phototherapy. Ind J Dermat, Vener Leprol. 2002;68:198-201.

29. Zhong JL, Yang L, Lu F, Xiao H, Xu R, Wang L, Zhu F, Zhang Y. UVA, UVB and UVC induce differential response signalling pathways converged on the elF2a phosphorylation. Photochem Photobiol. 2011;87:1092-104.

30. Tian FF, Zhang FF, Lai XD, Wang LJ, Yang L, Wang X, Singh G, Zhong J. Nrf2-mediated protection against UVA radiation in human skin keratinocytes. Biosci Trends. 2011:5:23-9.

31. Zhong JL, Raval C, Edwards GP, Tyrrell RM. A role for Bach1 and HO-2 in suppression of basal and UVA-induced $\mathrm{HO}-1$ expression in human keratinocytes. Free Rad Biol Med. 2010;48:196-206.

32. Yang SY, Zhou $B$, Wei $X$, Fangfang $X$, Nisar MF, Bian CX, Huang $X$, Li $Y$, Zhang Y, Bartsch JW, Zhong JL. Nrf2- and Bach1 may play a role in the 
modulation of UVA-induced oxidative stress by acetyl-11-keto- $\beta$ boswellic acid (AKBA) in skin keratinocytes. Skin Pharmacol Physiol. 2017;30:13-23.

33. Zhong JL. UVA Mediated iron release in skin cells. In: Thesis, the University of Bath, UK, Library; 2001.

34. Ma XQ, Hu H, Guo CX, Yu L, Gao LX, Xie JL, Li CM. DNA-templated biomimetic enzyme sheets on carbon nanotubes to sensitively in situ detect superoxide AnionsReleased from cells. Adv Funct Mater. 2014;24: 375897-903.

35. Yu L, Gao LX, Ma XQ, Hu FX, Li CM, Lu Z. Involvement of superoxide and nitric oxide in BRAF ${ }^{\mathrm{V} 600 \mathrm{E}}$ inhibitor PLX4032-induced growth inhibition of melanoma cells. Integr Biol. 2014;6:1211-7.

36. Buch K, Peters T, Nawroth T, Sanger M, Schmidberger H, Langguth P. Determination of cell survival after irradiation via clonogenic assay versus multiple MTT assay-a comparative study. Rad Oncol. 2012;7:1.

37. Stockert JC, Blazquez-Castro A, Canete M, Horobin RW, Villanueva A. MTT assay for cell viability: intracellular localization of the formazan product is in lipid droplets. Acta Histochem. 2012;114:785-96.

38. Grisham MB. Methods to detect hydrogen peroxide in living cells: possibilities and pitfalls. Comp Biochem Physiol A Mol Integr Physiol. 2013; 165:429-38.

39. Winterbourn CC. The challenges of using fluorescent probes to detect and quantify specific reactive oxygen species in living cells. Biochimicaet Biophysica Acta. 2014;1840:730-8

40. Sakagami H, Satoh K, Makino Y, Kojima T, Takeda M. Effect of alphatocopherol on cytotoxicity induced by UV irradiation and antioxidants. Antican Res. 1997;17:2079-82.

Ready to submit your research? Choose BMC and benefit from:

- fast, convenient online submission

- thorough peer review by experienced researchers in your field

- rapid publication on acceptance

- support for research data, including large and complex data types

- gold Open Access which fosters wider collaboration and increased citations

- maximum visibility for your research: over $100 \mathrm{M}$ website views per year

At BMC, research is always in progress.

Learn more biomedcentral.com/submissions 